\title{
Faktor yang Berhubungan dengan Terjadinya Infeksi Glostridium Difficile pada Penderita Diare akibat Antibiotik
}

\author{
Delfican, ${ }^{*}$ Yusri Dianne Jurnalis, * Hafni Bachtiar, ${ }^{* *}$ Andani Eka Putra ${ }^{* * *}$ \\ *Bagian Ilmu Kesehatan Anak RS. Dr. M. Djamil, Fakultas Kedokteran Universitas Andalas, Padang \\ **Bagian Ilmu Kesehatan Masyarakat, Fakultas Kedokteran Universitas Andalas, Padang \\ ***Bagian Mikrobiologi, Fakultas Kedokteran Universitas Andalas, Padang
}

Latar belakang. Pemakaian antibiotik yang tidak rasional dapat menyebabkan Clostridium Difficile Associated Diarrhea (CDAD).

Tujuan. Mengetahui proporsi CDAD, faktor yang berhubungan, dan antibiotik yang paling banyak menimbulkan CDAD.

Metode. Penelitian potong lintang terhadap anak yang mendapat antibiotik pada bulan Maret-September 2013. Clostridium Difficile Associated Diarrhea adalah ditemukannya gen $t c d B C$. difficile dari pemeriksaan PCR. Faktor risiko adalah umur, status gizi, jumlah, dosis, cara dan lama mendapat antibiotik. Analisis dilakukan secara bivariat dan multivariat.

Hasil. Terdapat 82 orang anak dengan proporsi CDAD 39\%. Persentasenya lebih tinggi pada usia 1 bulan-5 tahun, mendapat lebih dari 1 jenis antibiotik, dosis biasa, pemberian oral dan mendapat antibiotik kurang dari 7 hari dengan nilai $\mathrm{p}>\mathbf{0 , 0 5}$. Persentase CDAD hampir sama pada anak gizi baik dan gizi kurang. Persentase CDAD tertinggi didapatkan pada anak yang mendapat amoksisilin oral.

Kesimpulan. Proporsi CDAD cukup tinggi. Usia muda, jumlah antibiotik, pemberian dosis biasa secara oral dan waktu pemberian yang singkat menunjukkan kecenderungan menderita CDAD lebih besar, walaupun secara statistik tidak bermakna.Usia merupakan faktor paling dominan. Persentase CDAD tertinggi pada anak yang mendapat amoksisilin oral.

Sari Pediatri 2014;15(6):408-14.

Kata kunci: CDAD, proporsi, faktor yang berhubungan

Alamat korespondensi:

Dr. Delfican. Bagian Ilmu Kesehatan Anak RS. Dr. M. Djamil, Fakultas Kedokteran Universitas Andalas, Padang. Jln. Perintis Kemerdekaan, Padang. E-mail : delficanarif@yahoo.com.

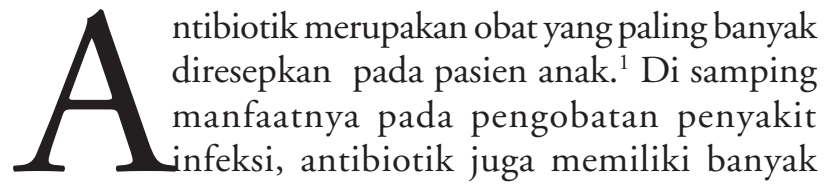


efek samping, di antaranya adalah diare yang disebut dengan antibiotic associated diarrhea (AAD). ${ }^{1-4}$

Antibiotic associated diarrhea adalah diare yang terjadi selama atau setelah pemberian antibiotik, penyebab lain tidak bisa ditemukan., ${ }^{5,6}$ Hampir 25\% diare akibat pemakaian antibiotik disebabkan oleh Clostridium difficile ( $C$. difficile) sehingga AAD sering juga disebut dengan clostridium difficile associated diarrhea (CDAD). ${ }^{7,8}$ Clostridium difficile merupakan bakteri anaerob, Gram positif yang menghasilkan spora dan 2 macam toksin, yaitu toksin A dan B. ${ }^{8-10}$ Toksin A memiliki efek enterotoksin, sedangkan toksin B memiliki efek sitotoksin. Efek sitopatik yang dihasilkan oleh toksin B 10 kali lebih poten dibandingkan dengan toksin A. ${ }^{8,11}$ Tidak semua strain akan menghasilkan toksin. Hanya strain yang toksigenik saja yang dapat menghasilkan toksin tersebut. ${ }^{8,12}$

Cytotoxicity assay merupakan baku emas dalam penegakan diagnosis, tetapi pemeriksaan ini membutuhkan waktu yang lama dan tenaga ahli yang sudah berpengalaman. ${ }^{13-15}$ Pemeriksaan PCR merupakan metode terbaru dalam penegakan diagnosis CDAD. Hasil pemeriksaan tersebut dapat langsung diketahui pada hari itu juga sehingga sangat membantu dalam tata laksana pasien lebih lanjut. ${ }^{16}$ Pemeriksaan ini dapat mendeteksi gen yang menyandi toksin $\mathrm{B}(t c d B)$ dari tinja serta memiliki sensitivitas dan spesifisitas yang tinggi, masing-masing 92\%-97\% dan 100\%. ${ }^{17}$

Terdapat beberapa faktor risiko yang berhubungan dengan terjadinya infeksi $C$. difficile yang menderita $\mathrm{AAD}$, yaitu antibiotik yang digunakan, umur, dan status gizi. ${ }^{18,19}$ Kejadian AAD dipengaruhi oleh dosis, jumlah, dan cara pemberiannya. ${ }^{3,20}$ Penelitian ini bertujuan untuk mengetahui proporsi CDAC, faktor yang memengaruhinya dan antibiotik yang paling banyak menimbulkan CDAD.

\section{Metode}

Penelitian potong lintang dilakukan di Bagian Ilmu Kesehatan Anak RS. Dr. M. Djamil Padang dan Laboratorium Biomedik Fakultas Kedokteran Universitas Andalas Padang pada bulan MaretSeptember 2013. Populasi adalah anak berusia 1 bulan - 14 tahun yang dirawat karena menderita diare serta semua anak yang mendapat terapi antibiotik.

Kriteria inklusi adalah anak yang dirawat karena diare dan terdapat riwayat pemberian antibiotik sebelumnya serta yang mendapat terapi antibiotik dan mengalami diare selama perawatan. Anak dengan kelainan kongenital pada saluran cerna seperti penyakit Hirschsprung dan yang mendapat obat pencahar tidak diikutsertakan dalam penelitian. Penelitian dilakukan setelah lulus seleksi dari Komite Etik RS. Dr. M. Djamil Padang. Informed consent diminta kepada orangtua pasien.

Isolasi DNA dilakukan dengan menggunakan QIAamp ${ }^{\circledR}$ DNA Stool Mini Kit (Qiagen). Amplifikasi DNA dilakukan dengan menggunakan metode Nested PCR yang didesain atas 2 primer, yaitu Outer Primer dan Inner Primer, sesuai dengan yang dikembangkan oleh Kato dkk ${ }^{21,22}$ (1998 dan 2005). Oligonukleotida untuk outer primer NK104 (5'-GTG TAG CAA TGA AAG TCC AAG TTT ACG C-3'; posisi 2945 - 2972) dan primer NK105 (5'-CAC TTA GCT CTT TGA TTG CTG CAC CT-3'; posisi 3123 - 3148) dengan ukuran sekitar 206 bp. Inner primer adalah NK201 (5'-TTT AGA TAC TAC ACA CGA AG-3') dan NK202 (5'-GCC ATT ATA CCT ATC TTA GC-3'). Elektroforesis DNA hasil amplifikasi dilakukan dengan menggunakan agarose gel 1,5\% dan difoto dengan menggunakan Gel Doc ${ }^{\mathrm{TM}}$ XR. Data dianalisis secara bivariat dan multivariat.

\section{Hasil}

Telah dilakukan penelitian terhadap 82 orang anak yang memenuhi kriteria inklusi dan eksklusi. Proporsi CDAD didapatkan 39\% (32 dari 82 orang anak). Sebagian besar sampel $(81,7 \%)$ adalah kelompok umur 1 bulan-5 tahun. Lebih dari separuh sampel $(54,9 \%)$ berjenis kelamin laki-laki dan mengalami gizi kurang (59,8\%). Karakteristik sampel tertera pada Tabel 1.

Tabel 1. Karakteristik sampel

\begin{tabular}{lcc}
\hline Karakteristik & $\mathrm{f}$ & $\%$ \\
\hline Kelompok umur & & \\
1 bulan-5 tahun & 67 & 81,7 \\
5-14 tahun & 15 & 18,3 \\
Jenis kelamin & & \\
$\quad$ Laki-laki & 45 & 54,9 \\
$\quad$ Perempuan & 37 & 45,1 \\
Status gizi & & \\
$\quad$ Kurang & 49 & 59,8 \\
$\quad$ Baik & 33 & 40,2 \\
\hline
\end{tabular}


Hasil analisis DNA dengan menggunakan elektroforesis tertera pada Gambar 1.
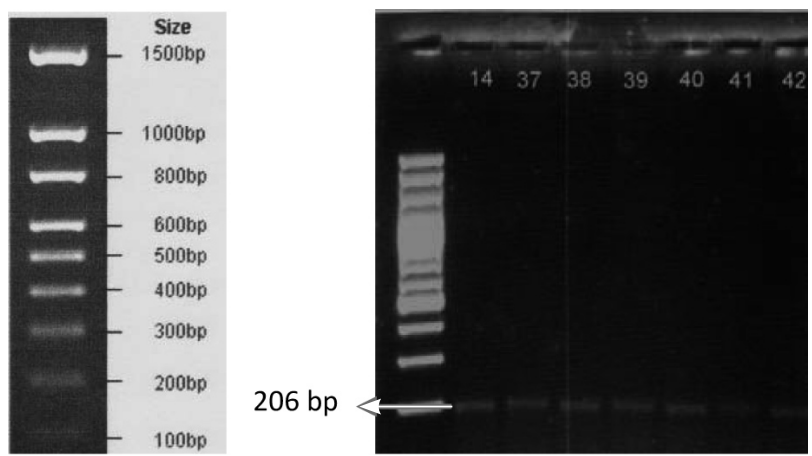

Gambar 1. Hasil elektroforesis DNA hasil amplifikasi PCR

Gambar 1 menunjukkan bahwa hasil isolasi DNA genom memiliki pita pada ukuran 206 bp. Hal ini mengindikasikan bahwa amplifikasi yang dilakukan berhasil. Sampel 14 merupakan sampel pertama yang berhasil diisolasi, diamplifikasi, dan dielektroforesis. Produk PCR tersebut lalu dilakukan sekuensing untuk melihat susunan DNAnya. Sekuensing dilakukan di Laboratorium Macrogen Korea. Data sekuens yang diperoleh lalu dibandingkan dengan database menggunakan program Basic Local Alignment Search Tool (BLAST). Hasil analisis BLAST terhadap sampel
14 didapatkan nilai Query coverage 89\%. Nilai Max ident sekuens didapatkan 100\%. Hal ini menunjukkan bahwa nilai sekuens data GenBank mendekati 100\% dengan sekuens yang kita masukkan sehingga sekuens yang dimasukkan sesuai dengan $C$. difficile strain HN587 toxin B (tcdB) gene. Sampel 14 lalu dijadikan sebagai kontrol internal untuk sampel yang lain.

Tabel 2 menunjukkan bahwa persentase CDAD lebih tinggi pada responden dengan kelompok umur 1 bulan- 5 tahun ( $43,3 \%$ vs $20 \%$ ), mendapat antibiotik lebih dari 1 jenis ( $47,4 \%$ vs $36,5 \%$ ), dosis biasa $(39,7 \%$ vs $33,3 \%)$, pemberian secara oral $(40,5 \%$ vs $37,5 \%)$ dan mendapatkan antibiotik kurang dari 7 hari $(42 \%$ vs $23,1 \%)$. Secara statistik perbedaan masing-masing faktor tersebut tidak bermakna $(p>0,05)$. Persentase CDAD juga hampir sama baik pada responden dengan status gizi kurang maupun gizi baik $(39,4 \%$ vs $38,8 \%)$. Berdasarkan analisis multivariat didapatkan faktor paling dominan yang berhubungan dengan CDAD adalah umur yaitu $\mathrm{p}=0,009$.

Persentase CDAD paling tinggi pada anak yang mendapat amoksisilin oral, $13(40,6 \%)$ orang, diikuti dengan sefotaksim intravena $4(12,5 \%)$, dan kombinasi ampisilin dengan kloramfenikol 3 (9,4\%). Persentase CDAD berdasarkan antibiotik tersebut tertera pada Tabel 3.

Tabel 2. Distribusi CDAD berdasarkan faktor risiko

\begin{tabular}{|c|c|c|c|c|c|c|c|}
\hline \multirow{3}{*}{ Faktor risiko } & \multicolumn{4}{|c|}{ CDAD } & \multirow{2}{*}{\multicolumn{2}{|c|}{ Total }} & \multirow{3}{*}{$\mathrm{p}$} \\
\hline & \multicolumn{2}{|c|}{ Ya } & \multicolumn{2}{|c|}{ Tidak } & & & \\
\hline & $\mathrm{f}$ & $\%$ & f & $\%$ & f & $\%$ & \\
\hline \multicolumn{8}{|l|}{ Kelompok umur } \\
\hline 1 bulan- 5 tahun & 29 & 43,3 & 38 & 56,7 & 67 & 100 & 0,168 \\
\hline 5-14 tahun & 3 & 20 & 12 & 80 & 15 & 100 & \\
\hline \multicolumn{8}{|l|}{ Status gizi } \\
\hline Kurang & 19 & 38,8 & 30 & 61,2 & 49 & 100 & 1,000 \\
\hline Baik & 13 & 39,4 & 20 & 60,6 & 33 & 100 & \\
\hline \multicolumn{8}{|c|}{ Jumlah antibiotik (jenis) } \\
\hline 1 & 23 & 36,5 & 40 & 63,5 & 63 & 100 & 0,560 \\
\hline$>1$ & 9 & 47,4 & 10 & 52,6 & 19 & 100 & \\
\hline \multicolumn{8}{|l|}{ Dosis } \\
\hline Biasa & 29 & 39,7 & 44 & 60,3 & 73 & 100 & 1,000 \\
\hline Tinggi & 3 & 33,3 & 6 & 66,7 & 9 & 100 & \\
\hline \multicolumn{8}{|l|}{ Cara pemberian } \\
\hline Oral & 17 & 40,5 & 25 & 59,5 & 42 & 100 & 0,960 \\
\hline Intravena & 15 & 37,5 & 25 & 62,5 & 40 & 100 & \\
\hline \multicolumn{8}{|c|}{ Lama mendapat antibiotik (hari) } \\
\hline$\leq 7$ & 29 & 42 & 40 & 58 & 69 & 100 & 0,330 \\
\hline$>7$ & 3 & 23,1 & 10 & 42 & 13 & 100 & \\
\hline
\end{tabular}


Tabel 3. Distribusi frekuensi CDAD berdasarkan pilihan antibiotik

\begin{tabular}{lcc}
\hline Pilihan antibiotik & $\mathrm{f}$ & $\%$ \\
\hline Amoksisilin oral & 13 & 40,6 \\
Sefotaksim intravena & 4 & 12,5 \\
Ampisilin + kloramfenikol iv & 3 & 9,4 \\
Amoksisilin + gentamisin iv & 2 & 6,3 \\
Sefiksim oral & 2 & 6,3 \\
Seftriakson iv & 1 & 3,1 \\
Meropenem iv & 1 & 3,1 \\
Seftriakson + meropenem iv & 1 & 3,1 \\
Amoksisilin + gentamisin iv & 1 & 3,1 \\
Ampisilin + kloramfenikol + seftriakson iv & 1 & 3,1 \\
Amoksisilin + kloramfenikol iv & 1 & 3,1 \\
Sefadroksil oral & 1 & 3,1 \\
Kotrimoksazol oral & 1 & 3,1 \\
\hline Jumlah & 32 & 100 \\
\hline
\end{tabular}

\section{Pembahasan}

Diare merupakan salah satu efek samping terbanyak yang mengenai saluran cerna pada anak yang mendapatkan antibiotik. ${ }^{3}$ Berdasarkan penelitian yang dilakukan oleh Oyofo $\mathrm{dkk}^{24}$ didapatkan insiden CDAD 1,3\%. Damayanti $\mathrm{dkk}^{25}$ melaporkan insiden AAD di RS. Dr. Sardjito Yogyakarta 31,1\% pada tahun 2006, anak laki-laki lebih banyak daripada anak perempuan $(39,6 \%$ vs $15,4 \%)$. Berdasarkan penelitian yang dilakukan oleh Samie $\mathrm{dkk}^{28}$ dengan menggunakan PCR, C. difficile strain toksigenik ditemukan pada $7,1 \%$ kasus dan memiliki hubungan dengan terjadinya diare.

Proporsi CDAD penelitian kami tidak jauh berbeda dengan yang didapatkan oleh Damayanti dkk, yaitu 39\%. Anak laki-laki (53,1\%) lebih banyak menderita CDAD. Umur termuda adalah 2 bulan dan tertua 14 tahun. Hasil penelitian kami juga tidak jauh berbeda dengan penelitian yang dilakukan oleh Kim $\mathrm{dkk}^{27}$ yang mendapatkan anak laki-laki lebih banyak menderita CDAD (54\%).

Turck $\mathrm{dkk}^{18}$ melaporkan insiden AAD lebih tinggi pada anak yang berumur kurang dari 2 tahun (18\% vs 3\%). Hasil penelitian kami menunjukkan bahwa persentase CDAD lebih tinggi pada responden dengan kelompok umur 1 bulan- 5 tahun dibandingkan dengan umur 5-14 tahun (43,3\% vs 20\%). Garcia dkk ${ }^{26}$ dan Damrongmanee $\mathrm{dkk}^{3}$ juga tidak menemukan adanya hubungan antara umur yang lebih muda dengan terjadinya CDAD.

Aboudola $\mathrm{dkk}^{29}$ melaporkan terdapat hubungan yang kuat antara respon antibodi serum terhadap toksin A dan efek proteksi terhadap CDAD. ${ }^{29}$ Wullt $\mathrm{dkk}^{30}$ mendapatkan kadar IgG antitoksin A dan B lebih rendah pada kelompok CDAD dibandingkan dengan kontrol. Hasil penelitian kami berbeda dengan kepustakaan yang ada, persentase CDAD ternyata hampir sama baik pada responden dengan status gizi kurang maupun gizi baik (39,4\% vs 38,8\%). Hasil penelitian kami sama dengan penelitian yang dilakukan oleh Kyne $\mathrm{dkk}^{31}$ yang tidak menemukan adanya efek proteksi dari respon imun terhadap kolonisasi C. difficile, walaupun pada penelitian tersebut ditemukan adanya hubungan antara respon sistemik terhadap toksin A. Hubungan tersebut dibuktikan dengan adanya peningkatan kadar IgG anti toksin A serum. $^{31}$

Penggunaan antibiotik jangka lama dan pemakaian kombinasi dua atau lebih antibiotik dapat meningkatkan risiko terjadinya CDAD ${ }^{32}$ Hasil penelitian kami menunjukkan bahwa persentase CDAD lebih tinggi pada responden yang mendapat antibiotik lebih dari satu jenis dibandingkan dengan yang mendapat satu jenis antibiotik (47,4\% vs $36,5 \%)$. Damrongmanee $\mathrm{dkk}^{3}$ juga tidak menemukan adanya hubungan antara jumlah antibiotik yang diberikan dengan terjadinya CDAD. Dutta $\mathrm{dkk}^{19}$ mendapatkan bahwa kombinasi antibiotik dapat menyebabkan CDAD pada $23 \%$ kasus. Giannella ${ }^{33}$ menyatakan bahwa CDAD lebih banyak ditemukan pada anak yang mendapatkan kombinasi antibiotik dibandingkan dengan antibiotik tunggal.

Hasil penelitian kami menunjukkan bahwa persentase CDAD lebih tinggi pada responden yang mendapat antibiotik dosis biasa dibandingkan dengan dosis tinggi $(39,7 \%$ vs $33,3 \%)$. Hal tersebut disebabkan karena lebih dari separuh responden dengan CDAD yang mendapat antibiotik dosis biasa juga mendapatkan antibiotik secara oral. Sesuai dengan kepustakaan, insiden CDAD lebih banyak terjadi pada anak yang mendapatkan antibiotik secara oral. Damrongmanee $\mathrm{dkk}^{3}$ juga tidak menemukan adanya hubungan antara tingginya dosis antibiotik yang diberikan dengan terjadinya CDAD.

Angka kejadian diare akibat pemberian obat secara parenteral terutama yang mengalami sirkulasi enterohepatik hampir sama dengan pemberian obat 
secara oral. ${ }^{5,11,18,20,25}$ Hasil penelitian kami menunjukkan bahwa persentase CDAD lebih tinggi pada responden yang mendapat antibiotik secara oral dibandingkan dengan intravena $(40,5 \%$ vs $37,5 \%)$.

Cohen $^{34}$ menyatakan bahwa lamanya rawatan memengaruhi terjadinya CDAD. Hasil penelitian kami menunjukkan bahwa persentase CDAD lebih tinggi pada responden yang mendapat antibiotik kurang dari 7 hari dibandingkan dengan lebih dari 7 hari (42\% vs $23,1 \%)$. Pada penelitian ini juga didapatkan diare paling cepat terjadi 3 hari setelah mendapat antibiotik dan paling lama 15 hari setelah mendapat antibiotik.

Hasil penelitian kami berbeda dengan penelitian yang dilakukan oleh Garcia $\mathrm{dkk}^{26}$ yang melaporkan CDAD lebih banyak terjadi pada pasien yang mengalami diare setelah mendapat antibiotik selama 7 hari. Berdasarkan penelitian yang dilakukan oleh Dutta $\mathrm{dkk}^{19}$ didapatkan CDAD terjadi setelah anak mendapat antibiotik selama $16,8( \pm$ SD2,5) hari. Turck $\mathrm{dkk}^{18}$ melaporkan AAD terjadi setelah anak mendapat antibiotik selama 5,3 $\pm 3,5$ hari. Berdasarkan penelitian yang dilakukan oleh Damrongmanee $\mathrm{dkk}^{3}$ didapatkan diare akibat antibiotik lebih banyak terjadi dalam 5 hari pertama setelah mengkonsumsi antibiotik, yaitu hari ke 2,28 $\pm 1,13$.

Pada penelitian kami, faktor umur adalah faktor paling dominan yang berhubungan dengan CDAD. Turck $\mathrm{dkk}^{18}$ mendapatkan 2 faktor risiko utama, yaitu umur anak dan jenis antibiotik yang digunakan. Mc Farland ${ }^{35}$ menyatakan bahwa jenis antibiotik yang digunakan merupakan prediktor kuat terjadinya AAD.

Persentase CDAD paling tinggi pada anak yang mendapat amoksisilin oral $(40,6 \%)$, diikuti dengan sefotaksim intravena $(12,5 \%)$, dan kombinasi ampisilin dengan kloramfenikol (9,4\%). Dutta $\mathrm{dkk}^{19}$ melaporkan CDAD terjadi pada anak yang mendapat ampisilin, sefalosporin dan gentamisin baik diberikan secara tunggal maupun dalam kombinasi. Sedangkan Turck dkk ${ }^{18}$ mendapatkan amoksisilinasam klavulanat (23\%), eritromisin (16\%), dan penisilin A dan M (11\%) yang merupakan antibiotik terbanyak menimbulkan CDAD. Berdasarkan penelitian yang dilakukan oleh Damayanti $\mathrm{dkk}^{25}$ didapatkan antibiotik terbanyak menimbulkan AAD adalah kombinasi ampisilin dengan sefotaksim intravena $(17,4 \%)$, amoksisilin oral (13\%), kombinasi ampisilin oral dengan kloramfenikol oral $(8,7 \%)$.
Terdapat beberapa keterbatasan pada penelitian kami. Penjaringan kasus AAD sebaiknya dilakukan secara lebih selektif lagi. Berdasarkan kepustakaan dinyatakan bahwa kolonisasi $C$. difficile dapat ditemukan pada $50 \%$ bayi sehat yang berumur di bawah 1 tahun, maka sebaiknya sampel yang berumur di bawah 1 tahun tidak diikutkan dalam penelitian. Kriteria yang digunakan dalam menegakkan diagnosis AAD juga harus diperketat. Berdasarkan beberapa penelitian yang dilakukan, terdapat beberapa variasi mengenai jumlah hari diare. Ada peneliti yang mengambil sampel tinja setelah anak mengalami diare selama 2 hari, 3 hari, bahkan ada yang 5 hari. , $^{3,18,19,36,37}$

Sesuai dengan definisi AAD, maka terlebih dahulu terhadap semua sampel sebaiknya dilakukan pemeriksaan penyaring untuk menyingkirkan penyebab diare yang lain seperti rapid test untuk menyingkirkan koinfeksi oleh rotavirus atau biakan tinja untuk menyingkirkan mikroorganisme lain. Dengan pemeriksaan ini, diharapkan hasil negatif dapat dikurangi. Namun demikian, rapid test dan biakan tinja tersebut tidak dilakukan karena kendala biaya.

Penelitian kami tidak membahas mengenai manifestasi klinis CDAD yang dialami oleh sampel dan pengaruh beratnya penyakit dasar terhadap CDAD. Wistrom dkk ${ }^{38}$ mendapatkan insiden AAD lebih tinggi pada sampel yang menderita keganasan disertai dengan satu atau lebih penyakit lain. Turck $\mathrm{dkk}^{18}$ menyatakan lokasi terjadinya infeksi tidak memengaruhi terjadinya AAD. Pada penelitian kami, juga tidak bisa ditentukan apakah $C$. difficile yang ditemukan merupakan strain toksigenik atau nontoksigenik. Oleh karena itu, dibutuhkan penelitian lebih lanjut mengenai toksigenisitas $C$. difficile tersebut.

\section{Kesimpulan}

Disimpulkan bahwa proporsi CDAD cukup tinggi. Semakin muda umur, semakin banyak pemakaian antibiotik, pemberian antibiotik dosis biasa secara oral dan semakin singkat pemakaian antibiotik, maka kemungkinan menderita CDAD cenderung menjadi lebih besar. Kecenderungan untuk menderita CDAD hampir sama berdasarkan status gizi. Umur merupakan faktor paling dominan. Persentase CDAD paling tinggi pada anak yang mendapat amoksisilin oral. 


\section{Daftar pustaka}

1. Arvola T, Laiho K, Torkkeli S. Prophylactic Lactobacillus GG reduces antibiotic-associated diarrhea in children with respiratory infections : a randomized study. Pediatrics 1999;104:1-4.

2. Sayoeti Y. Antibiotic associated diarrhea. Disampaikan pada Kongres Nasional III. Badan Koordinasi Gastroentrologi Anak Indonesian (BKGAI). Surabaya 2007:6974.

3. Damrongmanee A, Ukarapol N. Incidence of antibiotic associated diarrhea in a pediatric ambulatory care setting. J Med Assoc Thai 2007;90:513-7.

4. Schorling JB, De Souza MA, Guerrant RL. Antibiotic use among children in an urban Brazilian slum : a risk factor for diarrhea? Am J Public Health 1991;81:99-100.

5. Bartlett JG. Antibiotic-associated diarrhea. N Engl J Med 2002;346:334-9.

6. Young VB, Schmidt TM. Antibiotic-associated diarrhea accompanied by large scale alterations in the composition of the fecal microbiota. J Clin Microbiol 2004;42:1203-6.

7. Hickson M. Probiotics in the prevention of antibioticassociated diarrhoea and Clostridium difficile infection. Ther Adv Gastroenterol 2011;4:185-97.

8. Ayyagary A, Agarwal J, Garg A. Antibiotic-associated diarrhea : Infectious causes. Indian J Med Microbiol 2003;21:6-11.

9. Hall IC, O'Toole E. Intestinal flora in newborn infants with a description of a new pathogenic anaerobe, Bacillus difficilis. Am J Dis Child 1935;49:390-402.

10. Carter GP, Rood JI, Lyras D. The role of toxin A and toxin B in Clostridium difficile-associated disease, past and present perspectives. Gut Microbes 2010;1:58-64.

11. Klingler PJ, Metzger PP, Seelig MH, Pettit PDM, Knudsen JM, Alvarez S. Clostridium difficile infection: risk factors, medical and surgical management. Dig Dis 2000;18:147-60.

12. Turgeon DK, Novicki TJ, Quick J. Six rapid tests for direct detection of Clostridium difficile and its toxins in fecal samples compared with the Fibroblast Cytotoxicity Assay. J Clin Microbiol 2003;41:667-70.

13. Luna RA BJB, Mehta S, Courtney EM, Webb CR, Revell PA, Versalovic J. Rapid stool-based diagnosis of Clostridium difficile infection by Real-Time PCR in a children's hospital. J Clin Microbiol 2011;49:851-7.

14. Kvach EJ, Ferguson D, Riska PF, Landry ML. Comparison of BD GeneOhm Cdiff Real-Time PCR assay with a two-step algorithm and a toxin A/B EnzymeLinked Immunosorbent Assay for diagnosis of toxigenic
Clostridium difficile infection. J Clin Microbiol 2010;48:109-14.

15. Barbut F, Braun M, Burghoffer B, Lalande V, Eckert C. Rapid detection of toxigenic strains of Clostridium difficile in diarrheal stools by Real-Time PCR. J Clin Microbiol 2009;47:1276-7.

16. Larson AM, Fung AM, Fang FC. Evaluation of $t c d B$ Real-Time PCR in a three-step diagnostic algorithm for detection of toxigenic Clostridium difficile. J Clin Microbiol 2010;48:124-30.

17. Gerding DN, Muto CA, Owens RC. Treatment of Clostridium difficile infection. CID 2008;46:S32-42.

18. Turck D, Bernet JP, Marx J. Incidence and risk factors of oral antibiotic-associated diarrhea in an outpatient pediatric population. J Pediatr Gastroenterol Nutr 2003;37:22-6.

19. Dutta P, Niyogi SK, Mitra U. Clostridium difficile and antibiotic associated pediatric diarrhea. Indian Pediatr 1994;31:121-6.

20. Alam S, Mushtaq M. Antibiotic associated diarrhea in children. Indian Pediatrics 2009;46:491-6.

21. Kato H, Kato N, Watanabe K, et al. Identification of Toxin A-Negative, Toxin B-Positive Clostridium difficile by PCR. J Clin Microbiol 1998;36:2178-82.

22. Kato H, Yokoyama T, Arakawa Y. Typing by sequencing the slpA gene of Clostridium difficile strains causing multiple outbreaks in Japan. J Med Microbiol 2005;54:167-71.

23. Collins DA. Hawkey PM. Riley TV. Epidemiology of Clostridium difficile infection in Asia. Antimicrobial Resistance and Infection Control 2013;2:1-9.

24. Oyofo BA, Subekti D, Tjaniadi P. Enteropathogens associated with acute diarrhea in community and hospital patients in Jakarta, Indonesia. FEMS Immunol Med Microbiol 2002;34:139-46.

25. Damayanti W DI, Synthana MR, Juffrie M. Antibiotic associated diarrhea di rumah sakit Dr. Sardjito Yogyakarta. JGAI 2006;2:31-4.

26. Garcia C, Samalvides F, Vidal M, Gotuzzo E, Dupont HL. Epidemiology of Clostridium difficile-associated diarrhea in a Peruvian tertiary care hospital. Am J Trop Med Hyg 2007;77:802-5.

27. Kim J SS, Prasad P, Leckerman KH, Coffin S, Zaoutis T,. Epidemiological features of Clostridium difficileAssociated Disease among inpatients at Children's Hospitals in the United States, 2001-2006. Pediatrics 2008;122:1266-70.

28. Samie A OC, Franasiak J, Archbald-Pannone L, Bessong PO, Alcantara-Warren C, Guerrant RL. PCR Detection of Clostridium difficile Triose Phosphate Isomerase (tpi), 
Toxin A (tcdA), Toxin B (tcdB), Binary Toxin (cdtA, $\mathrm{cdtB}$ ), and tcdC Genes in Vhembe District, South Africa. Am J Trop Med Hyg 2008;78:577-85.

29. Aboudola S KK, Kyne L, Warny M, Kelly EC, Sougioultzis S, Giannasca PJ, Monath TP, Kelly CP. Clostridium difficile Vaccine and Serum Immunoglobulin G Antibody Response to Toxin A. Infection and Immunity 2003;71:1608-10.

30. Wullt M NT, Ljungh A, Åkerlundd T. IgG Antibody Response to Toxins A and B in Patients with Clostridium difficile Infection. Clinical and Vaccine Immunology 2012;19:1552-4.

31. Kyne L WM, Qamar A, Kelly CP. Asymptomatic carriage of Clostridium difficile and serum levels of IgG antibody against toxin A. N Engl J Med 2000;342:390-7.

32. O'Connor KA, Kingston M, O’Donovan M, Cryan B, Twomey P, O'Mahony D. Antibiotic prescribing policy and Clostridium difficile diarrhoea. QJ Med 2004;97:423-9.

33. Giannella RA. Antibiotic-associated diarrhea and Clostridium difficile: an update. Rev Esp Enferm Dig
2001;93:535-43.

34. Cohen MB. Clostridium difficile Infections: Emerging Epidemiology and New Treatments. Journal of Pediatric Gastroenterology and Nutrition 2009;48:S63-S5.

35. McFarland LV. Meta-analysis of probiotics for the prevention of antibiotic associated diarrhea and the treatment of Clostridium difficile disease. Am J Gastroenterol 2006;101:812-22.

36. Ferreira CEA, Nakano V, Durigon EL, Campos MJA. Prevalence of Clostridium spp. and Clostridium difficile in children with acute diarrhea in São Paulo city, Brazil. Mem Inst Oswaldo Cruz 2003;98:451-4.

37. Gogate A DA, Nanivadekar R, Mathur M, Saraswathi K, Jog A, Kulkarni MV. Diagnostic role of stool culture and toxin detection in antibiotic associated diarrhea due to Clostridium difficile in children. Indian J Med Res 2005;122:518-24.

38. Wistrom J, Norrby SR, Myhre EB, et al. Frequency of antibiotic-associated diarrhea in 2462 antibiotic-treated hospitalized patients : a prospective study. J Antimicrob Chemother 2001;47:43-50. 